УДК 551.21/23

\title{
ГЕОХИМИЯ ПАРОГИДРОТЕРМ КОШЕЛЕВСКОГО ВУЛКАНИЧЕСКОГО МАССИВА (ЮЖНАЯ КАМЧАТКА)
}

\author{
(C) 2016 г. Е. Г. Калачева' ${ }^{\text {, C. Н. Рычагов }}{ }^{1}$, Г. П. Королева², А. А. Нуждаев ${ }^{1}$ \\ ${ }^{1}$ Институт вулканологии и сейсмологии ДВО РАН \\ 683006 Петропавловск-Камчатский, бульвар Пийпа, 9, \\ e-mail:keg@kscnet.ru \\ ${ }^{2}$ Институт геохимии им. А.П. Виноградова СО РАН \\ 664033 Иркутск, ул. Фаворского, 1 а \\ Поступила в редакцию 26.02.2015 г.
}

\begin{abstract}
Приведены новые данные по геохимии термальных вод Кошелевского вулканического массива на юге Камчатки. Рассмотрены условия формирования термальных вод, возможные варианты теплового и глубинного вещественного питания Кошелевской гидротермальной системы и предложена ее концептуальная модель.
\end{abstract}

DOI: $10.7868 / \mathrm{S} 0203030616030044$

\section{ВВЕДЕНИЕ}

Кошелевский вулканический массив (на географических картах - вулкан Кошелева) является одним из наиболее сложных вулканических сооружений Камчатки [Долгоживущий ..., 1980]. Он расположен на южной оконечности полуострова в зоне сочленения трех вулканических поясов и на стыке региональных камчатских и курильских структур. Кошелевский массив вмешает крупную гидротермальную систему, поверхностные проявления которой представлены Верхнекошелевскими и Нижнекошелевскими термальными полями, и разгружающимися по периферии термальными (до $40^{\circ} \mathrm{C}$ ) водами различного состава. Наиболее интенсивно район Кошелевского массива и его гидротермальные системы изучались в 50-70-ые годы XX века, когда были проведены геологические, геофизические, гидрогеологические исследования и ряд тематических работ [Сережников и др., 1973; Сережников, Спиченкова, 1978; Структура ..., 1993; Поздеев, Нажалова, 2008; Манухин, Павлова, 2011; и др.]. Подробная характеристика основных термальных полей и оценка их тепловой мощности представлена в [Вакин и др., 1976]. С помощью бурения скважин в пределах Нижнекошелевского термального поля вскрыт геологический разрез до глубины 1.5 км и выделено одно из крупнейших на Камчатке Нижнекошелевское пародоминирующее геотермальное месторождение [Писарева, 1987]. Результаты детального изучения состава и свойств измененных пород месторождения представлены в работах [Рычагов и др., 2009, 2012; и др.]. В то же время, многие вопросы, связанные с источником теплового питания гидротермальной системы, условиями фор- мирования и разгрузки, связанных с ней термальных вод, остались открытыми.

В настоящей статье на основании детального гидрохимического опробования, проводимого в течение нескольких летних полевых сезонов на склонах Кошелевского массива, приводятся новые данные по общему химическому составу разгружающихся термальных вод. Впервые приведены анализы микроэлементов, включая редкие земли, в термальных водах, а также изотопный состав стронция. Обсуждаются условия формирования паро-конденсатных термальных вод Кошелевской гидротермальной системы, а также ее глубинное строение.

\section{МЕТОДЫ ИССЛЕДОВАНИЯ}

Измерения физико-химических параметров термальных и холодных вод (pH, Еh и температура) проводились непосредственно в точке отбора портативным анализатором Multi 340i/SET фирмы WTW. Пробоподготовка для дальнейшего химического анализа проводилась стандартными методами, включая фильтрование через Micropore фильтр $0.45 \mu$. Отобранные пробы для изучения микроэлементов подкислялись сверхчистой $\mathrm{HNO}_{3}$ до $\mathrm{pH}=2$. Общий химический анализ, включающий определение ионов $\mathrm{NH}_{4}^{+}, \mathrm{Na}^{+}, \mathrm{K}^{+}$, $\mathrm{Ca}^{2+}, \mathrm{Mg}^{2+}, \mathrm{HCO}_{3}^{-}, \mathrm{Cl}^{-}, \mathrm{F}^{-}, \mathrm{SO}_{4}^{2-}, \mathrm{B}, \mathrm{SiO}_{2}$ проводился в аналитическом центре Института вулканологии и сейсмологии ДВО РАН. Анализ микроэлементного состава выполнялся в аналитическом центре Института геохимии им. А.П. Виноградова СО РАН методом индуктивной плазменной массспектрометрии (ICP-MS). Обработка гидрогеохи-

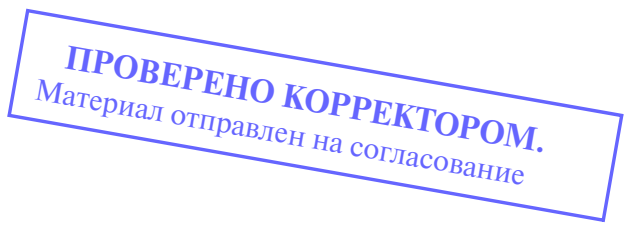


мических данных и графическое отображение химического состава термальных вод проводились с помощью компьютерной программы AQUACHEM 5.1 [AquaChem ..., 2006].

\section{ГЕОЛОГО-ГИДРОГЕОЛОГИЧЕСКАЯ ХАРАКТЕРИСТИКА РАЙОНА}

Кошелевский вулканический массив входит в структуру Паужетско-Камбально-Кошелевского геотермального (рудного) района. Район представляет собой долгоживущий (с раннего олигоцена по голоцен) вулканогенно-рудный центр [Долгоживущий центр ..., 1980]. Породы района типичны для островодужного комплекса и составляют три структурных яруса [Геолого-геофизический ..., 1987]. Нижний ярус олигоцен-среднемиоценового возраста сложен лавами, туфами и вулканогенно-осадочными породами от основного до кислого состава, вмещающими многофазные интрузии от габбро до плагиогранитов. Средний ярус миоцен-плиоценового возраста представлен вулканогенно-осадочными породами (туффитами с прослоями лав и туфов) основного и среднего состава. Верхний ярус представлен лавами, туфами, экструзиями и субвулканическими интрузиями от андезито-дацитов до базальтов (преобладают породы среднего состава) плейстоцен-голоценового возраста. К этому комплексу относится Кошелевский вулканический массив. В основании массива залегают породы среднего структурного яруса, в пределах которого широко распространены вторичные кварциты, монокварциты и аргиллизиты, вмещающие кварц-карбонат-сульфидные жилы и рассеянную рудную минерализацию. Кошелевский вулканический массив образован в интервале времени от нижнего плейстоцена по голоцен за счет эволюции магматического очага, сформировавшегося на пересечении крупнейших южнокамчатских разломных зон [Вакин и др., 1976; Лебедев, Декусар, 1980]. На начальном нижнечетвертичном этапе вулканизма образовались два крупных базальтовых вулкана Третья Речка и "Дед и Баба". Собственно Кошелевский массив сложен полуразрушенными постройками пяти стратовулканов возрастом от нижнего плейстоцена по голоцен: Древний, Западный, Валентин, Центральный и Восточный. Детальное описание их образования, строения и слагающих пород приведено в работах [Сережников и др., 1973; Долгоживущий центр ..., 1980; Нуждаев, Феофилактов, 2013].

В гидрогеологическом отношении Кошелевский вулканический массив является вулканогенным бассейном [Манухин, Павлова, 2011]. Основанием бассейна служат водоносные комплексы вулканогенно-осадочных пород среднего структурного яруса, а также толща нижнечетвертичных лав вулканов Третья Речка и “Дед и Баба". Бассейн сложен водоносными комплексами верхне- го структурного яруса. Питание водоносных комплексов происходит, в основном, за счет атмосферных осадков, а также, вероятно, вследствие притока вод Охотского моря. В результате бурения скважин в районе Нижне-Кошелевского термального поля до глубины 1500 м показано глубинное строение гидротермальной системы, приуроченной к Кошелевскому вулканическому массиву [Писарева, 1987]. Циркуляция термальных вод в недрах системы и инфильтрация на глубину метеорных вод происходит по субвертикальным трещинно-брекчиевым зонам на фоне общей низкой проницаемости пород резервуapa. На основании гидродинамических испытаний скважин выделена область сухого пара в форме конуса, расширяющаяся на глубину более 1.5 км от поверхности и выклинивающаяся на дневной поверхности в районе Нижнекошелевского термального поля. По геолого-геофизическим данным, под Нижнекошелевским полем выделяется вертикальная зона повышенной проницаемости, погружающаяся на глубину более 5 км [Рычагов, 2014]. Приповерхностная часть зоны представлена чашеобразной областью разуплотнения и аргиллизации пород, где происходит интенсивное смешение метеорных вод и восходящих парогазовых струй. Принципиально похожая гидрогеологическая обстановка может иметь место и в структуре Верхнекошелевского термального поля. Предполагается наличие гидравлической связи между термальными молями массива [Вакин и др., 1976; Поздеев, Нажалова, 2008] и, следовательно, они могут рассматриваться, как проявления единой Кошелевской гидротермальной системы.

\section{ОПИСАНИЕ ТЕРМОПРОЯВЛЕНИЙ КОШЕЛЕВСКОГО МАССИВА}

Детальное описание термальных полей Кошелевского массива приведено в [Вакин и др., 1976]. В данной работе приводится их краткая характеристика с акцентами на изменения, произошедшие за последние 40 лет. Физико-химические показатели приведены по состоянию на август 2009 г.

Верхнекошелевское термальное поле расположено в центральной части Кошелевского вулканического массива в эрозионном кратере вулкана Валентин на абсолютных отметках 1200-1250 м (рис. 1а). Общая площадь его оценена в $303000 \mathrm{~m}^{2}$ по изотерме $20^{\circ} \mathrm{C}$ на глубине 0.5 м [Вакин и др., 1976]. Гидрографическая сеть представлена тремя основными ручьями (Восточный, Западный, Дальний), вытекающими из-под снежников и сливающихся в единый поток (истоки реки Шумной) за пределами термального поля. Поверхность в пределах поля подвержена активной эрозии за счет взаимодействия большой массы метеорных вод с термопроявлениями и легко разрушающимися аргиллизированными горными породами, вследствие чего на площади широко развита сеть мелких ру- 
(a)
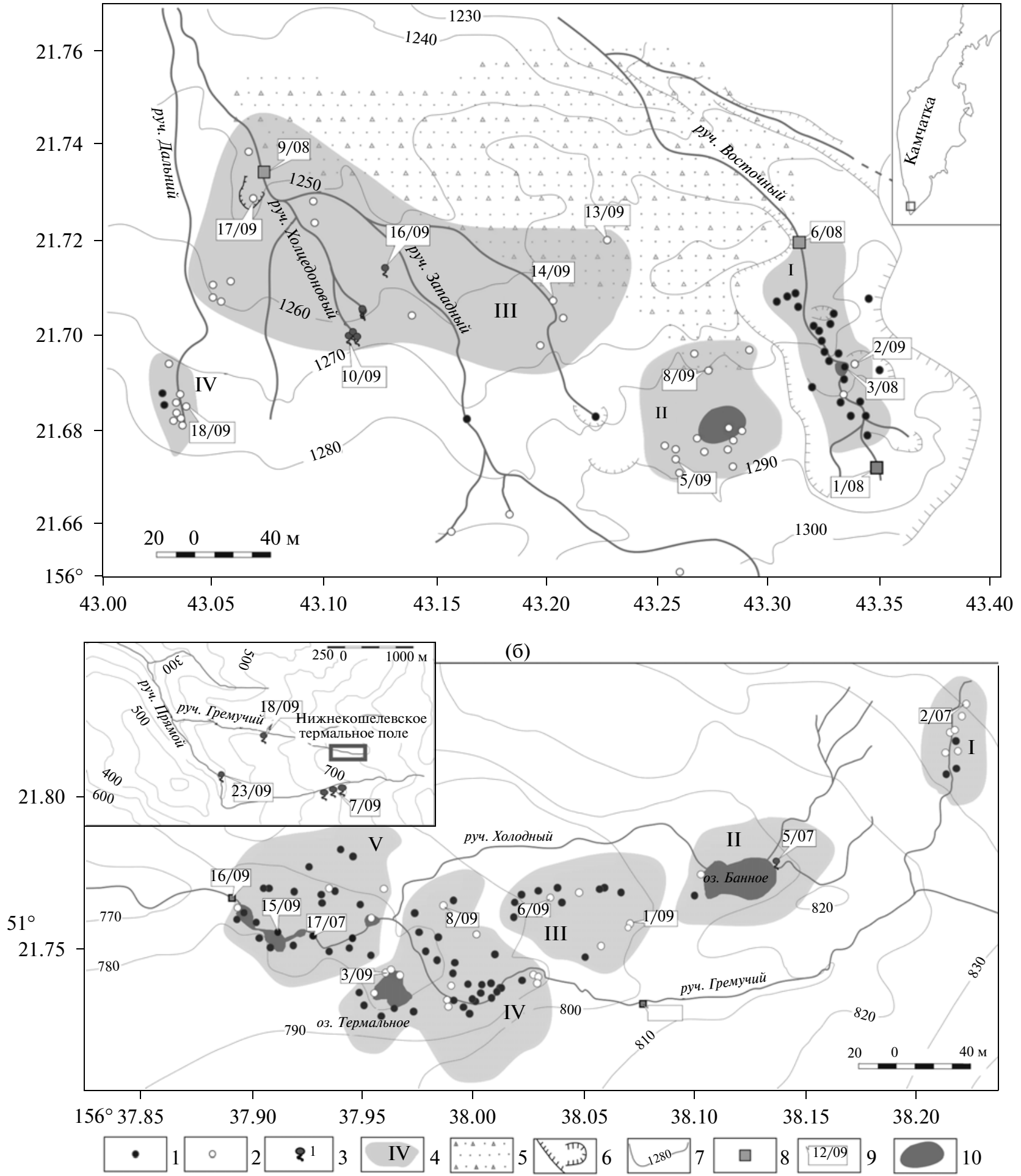

Рис. 1. Схемы расположения основных термопровлений Кошелевского массива.

а - Верхнекошелевское термальное поле; б - Нижнекошелевское термальное поле (на врезке термальные источники за его пределами).

1 - парогазовые струи; 2 - водногрязевые котлы; 3 - термальные источники; 4 - границы термальных участков; 5 область делювиальных отложений; 6 - эрозионные уступы; 7 - изолинии; 8 - гидростворы; 9 - номера водных проб; 10 - термальные озера. 
чьев, оврагов, западин. На площади поля, особенно в его северной части, также развиты крупноглыбовые делювиальные отложения.

Термопроявления представлены парогазовыми струями, водногрязевыми котлами, горячими источниками и озерцами, парящими грунтами. Всего здесь было выделено три участка: Тартарары, Полигон и Кислый [Вакин и др., 1976]. Парогазовая активность приурочена, в основном, к долине руч. Восточный (участок Тартарары). Максимальная измеренная температура (Т) парогазовых струй $150^{\circ} \mathrm{C}$. Расход струй оценен [Вакин и др, 1976] в 0.1-0.4 кг/c, скорость истечения в более чем 100 м/с. Для участка Полигон характерны бессточные или с незначительным стоком водоемы диаметром до 10 м с разрозненными интенсивно "кипящими" участками в местах выходов парогазовых струй и небольшие водногрязевые котлы Т $=75-$ $90^{\circ} \mathrm{C}, \mathrm{pH}=1.9-2.8, \mathrm{Eh}=+290 \ldots+325$ мВ. Участок Кислый занимает значительную часть термального поля и характеризуется всеми типами термопроявлений. Среди обвальных отложений, по бортам и в руслах ручьев расположены парогазовые выходы с Т до $120^{\circ} \mathrm{C}$. Отмечаются небольшие водногрязевые котлы и горячие источники. В северной части участка нами обнаружена неизвестная ранее группа горячих источников, дающая начало руч. Халцедоновый (см. рис. 1, т. 10/09в). Температура воды в источниках колеблется от 70 до $58^{\circ} \mathrm{C}$, значения $\mathrm{pH}=3.0-3.15, \mathrm{Eh}=+245 \mathrm{мB}$. Обломки породы в русле ручья покрыты щеточками кремнезема с размером кристаллов до 5 мм. На площади этого участка обнаружены еще два источника с похожими физико-химическими параметрами (т. 16/09в). Одним из наиболее крупных термопроявлений участка является водногрязевой котел "Пиритовый" (т. 17/09в). Назван нами так изза отложения по его бортам корочек пирита и образования на “кипящей” поверхности котла пленки, состоящей из тонких кристаллов сульфидов (пирит + марказит) и глинистых частиц. Температура воды в котле $86^{\circ} \mathrm{C}, \mathrm{pH}=5.9, \mathrm{Eh}=+60 \mathrm{мB}$.

Во время полевых работ 2009 г. был обнаружен не описанный ранее термальный участок, названный нами Дальний. Участок вскрылся в результате таяния многолетнего снежника. В последующие годы наблюдений границы этого участка расширились. Верхняя группа термопроявлений приурочена к делювиальным отложениям на перегибе крутого склона (т. 18/09в). На левом борту руч. Дальний расположено более десятка слабых парогазовых струй с $\mathrm{T}=98^{\circ} \mathrm{C}$, а рядом с руслом находятся небольшие бессточные водногрязевые котлы с $\mathrm{T}=90-94^{\circ} \mathrm{C}, \mathrm{pH}=4.6-4.9$. Часть котлов активно промывается водами от вышележащего снежника.

На наиболее высоких гипсометрических отметках Верхнекошелевского термального поля в верховьях ручьев Восточный и Западный широко развиты лимонит-гематитовые отложения, при- уроченные к выходам холодных $\left(\mathrm{T}=8-9^{\circ} \mathrm{C}\right)$ кислых $(\mathrm{pH}=3.1-3.5)$ грунтовых вод, дающих начало руч. Восточный и некоторым притокам руч. Западный. Вынос закисного железа, по-видимому, определяется его высокими концентрациями в окружающих аргиллизированных экструзивных андезидацитах, а также интенсивной фильтрацией метеорных вод.

Нижнекошелевское термальное поле (рис. 16) расположено на западном склоне Кошелевского вулканического массива на абсолютных отметках 770-850 м и приурочено к овально-кольцевой отрицательной геоморфологической структуре, вытянутой на 500 м вдоль глубоко врезанного оврага руч. Гремучий. Руч. Гремучий берет начало из-под многолетних снежников на восточной границе поля. Наиболее характерными термопроявлениями являются водногрязевые котлы, термальные озерца, парогазовые струи, парящие грунты. Температура грунтов не превышает $105^{\circ} \mathrm{C}$ (на глубине 0.8-3.0 м), максимальная измеренная Т парогазовых выходов $120^{\circ} \mathrm{C}$, при средних значениях в $90-98^{\circ} \mathrm{C}$.

На площади термального поля в настоящее время выделяются три участка. Участок Верхний находится в пологой ложбине размером $20 \times 40$ м в верховьях правого притока руч. Гремучий. В 1970-ые годы локализованная здесь разгрузка гидротерм входила в состав участка Восточный, занимавшего площадь до $30 \times 140$ м [Вакин и др., 1976]. Термальные источники, отмеченные ранее на слиянии правого притока с основным ручьем, в настоящее время не существуют. На участке Верхний насчитывается около 10 водногрязевых котлов диаметров до 30 см и парогазовых струй малой мощности (см. рис. 1б, т. 2/07). Температура воды в котлах составляет в среднем, $85-90^{\circ} \mathrm{C}, \mathrm{pH}$ варьирует от 4.5 до $5.5, \mathrm{Eh}=+100 \ldots+190$ мВ. В центре участка при расширении долины дренирующего ручья образуются теплые озерца $\left(30-35^{\circ} \mathrm{C}\right)$. Расход ручья ниже участка равен 3.0 л/с, $\mathrm{T}=23^{\circ} \mathrm{C}, \mathrm{pH}=5.4$, $\mathrm{Eh}=+88 \mathrm{MB}$.

Отдельным участком выделяется подпрудное озеро Банное (см. рис. 1б), использованное в период поисково-разведочных работ в качестве водозабора для бурения скважин. У восточного берега озера на площадке размером $1.0 \times 1.5$ м осуществляется разгрузка термальных вод (т. 5/07) с $\mathrm{pH}=7.0-7.4$. Температура воды источников в разные годы составляла $56-72^{\circ} \mathrm{C}$. Разгрузка термальных вод происходит и в самом озере, за счет этого масса воды прогревается до $35^{\circ} \mathrm{C}$, со дна поднимаются струйки газа. В этом месте Е.А. Вакиным с коллегами выделялась зона с температурами грунтов от 50 до $90^{\circ} \mathrm{C}$. В 5 м от западной границы озера Банное в 2010 г. была обнаружена парогазовая струя, температура которой за период с 2010 по 2013 гг. увеличилась с 103 до $111^{\circ} \mathrm{C}$.

Основная часть термопроявлений сконцентрирована на участке, в пределах которого на основании геоморфологических отличий можно выде- 
лить три условные зоны: Большая Сухая Воронка (БСВ), Центральная и Западная (см. рис. 1б). БСВ имеет неправильную изометрическую формы площадью 50 × 60 м с крутым восточным бортом, плоским дном, несколькими мелкими (до 5 м в диаметре) эрозионными воронками у западной границы и термальными буграми внутри структуры. В 20062009 гг. под крутым бортом БСВ находились два крупных и несколько мелких водногрязевых котлов. Струи горячей воды с большим количеством взвешенного вещества выбрасывались сквозь свалы крупных глыб андезитов на высоту до 1.5 м. В нижней части воронки располагался водоем, заполненный глинистым раствором (соотношение глинистой и водной фаз составляло 2 : 1). Температура жидкости в водоеме варьировала от $41^{\circ} \mathrm{C}$ в удаленных частях от котлов, до $94^{\circ} \mathrm{C}$ вблизи них. Диапазон рН для всех термопроявлений БСВ составил $4.1-4.5, \mathrm{Eh}=+175 \ldots+195$ мВ. Описываемые крупные водногрязевые котлы за период с 2006 по 2013 гг. непрерывно смещались к южной границе БСВ, превратившись в единый мощный котел удлиненной формы глубиной более 3.0 м и высотой выброса жидкости до 1.5-2.0 м. Котел прорезал южный борт БСВ, и в 2013 г. по эрозионной ложбине глинистый раствор разгружался уже непосредственно в руч. Гремучий. От западной части БСВ простирается линейная зона, трассируемая небольшим ручьем, в русле и по бортам которого расположено до 10 парогазовых струй и несколько котелков размером до 25-30 см. Температура парогазовой смеси достигает $113^{\circ} \mathrm{C}$, воды в котлах $-98^{\circ} \mathrm{C}, \mathrm{pH}$ колеблется от 5.3 до 6.8, $\mathrm{Eh}=$ $=+111 \ldots+225 \mathrm{MB}$.

Центральная зона (см. рис. 1б) расположена в наиболее широкой части долины руч. Гремучий. Изометричная в плане форма участка (кольцевая структура диаметром 100 м) образована в значительной степени вследствие интенсивной эрозии аргиллизированных отложений в бортах долины. На участке сосредоточена основная часть парогазовых струй и водногрязевых котлов различных размеров, в т.ч. наиболее мощных, сопоставимых с таковыми на Верхнекошелевском термальном поле. Температура воды в водногрязевых котлах $85-90^{\circ} \mathrm{C}, \mathrm{pH}=6.0-6.4, \mathrm{Eh}=+250 \ldots+295$ мВ. Парогазовые струи выходят непосредственно в русле ручья и вдоль всех водораздельных хребтиков и на склонах эрозионных воронок. По левому борту руч. Гремучий в крупной эрозионной воронке расположено озеро Термальное (см. рис. 1б), вдоль береговой линии которого расположены небольшие (до 1.0 м в диаметре) водногрязевые котлы с различными (до контрастных) физикохимическими параметрами: $\mathrm{T}=67-94^{\circ} \mathrm{C}, \mathrm{pH}=$ $=1.7-6.2, \mathrm{Eh}=+92 \ldots+256$ мВ и парогазовые выходы. Вода озера имеет желтовато-серый цвет за счет обилия взвеси самородной серы. В этой части термального поля, в русле руч. Гремучий происходит активное химическое выщелачивание и меха- ническое вымывание тонкой фракции аллювия с образованием подземных полостей, в которые периодически “проваливается” водный поток.

В Западной зоне большинство парогазовых выходов приурочены к руслу руч. Гремучий. Они формируют в нем участки с интенсивным "кипением" и выбросами воды на высоту до двух метров. Большую часть времени эти участки окутаны клубами пара. В среднем, температура воды в них составляет $82-84^{\circ} \mathrm{C}$, значения $\mathrm{pH}=5.5-6.2, \mathrm{Eh}=$ $=+85 \ldots+235$ мВ. В нижней части участка, на границе термального поля руч. Гремучий разливается в озеро размером $25 \times 30 \mathrm{M}^{2}$, вся поверхность которого "кипит" за счет обильного газовыделения. Озеро образовалось вследствие естественного выполаживания долины руч. Гремучий, а также за счет строительства в 1970-ые годы плотины высотой около 1.0 м. Плотина использовалась для измерения расходов воды в ручье. Дебит руч. Гремучего ниже плотины составляет по нашим измерениям 45 л/с.

Другие термальные источники Кошелевского вулканического массива. Помимо описанных выше термальных полей, на склонах Кошелевского массива расположены несколько групп или отдельных термальных источников: Кальдерные, Шумный, Сказка, Промежуточный, Сивучинские [Вакин и др., 1976]. Нами обследованы источники Промежуточный и Сказка и обнаружена новая разгрузка термальных вод в среднем течении руч. Прямой. Источник Промежуточный (см. рис. 1б, т. 23/09) находится в нижней части долины руч. Прямой на правом борту: $\mathrm{T}=18-20^{\circ} \mathrm{C}$, $\mathrm{pH}=7.9, \mathrm{Eh}=+37$ мВ. Источник формирует короткий ручей дебитом 12-15 л/с, впадающий в основной водоток. Источники Сказка (т. 18/09) расположены на левом берегу руч. Гремучий в 3 км ниже Нижнекошелевского термального поля. Их общий дебит меньше 1.0 л/с, температура воды не превышает $23^{\circ} \mathrm{C}, \mathrm{pH}=6.1, \mathrm{Eh}=+49 \mathrm{MB}$. В среднем течении руч. Прямой в его левом борту на абсолютной отметке 675 м в 2005 г. обнаружены не описанные ранее источники (см. рис. 16 врезка, т. 7/09) с температурой $69.5^{\circ} \mathrm{C}, \mathrm{pH}=7.6, \mathrm{Eh}=-40 \mathrm{MB}$. Разгрузка термальных вод образует субгоризонтальную цепочку из локальных выходов, трассирующих подошву лавового потока андезито-дацитов. Физико-химические характеристики вод последовательно менялись в период наблюдений. К 2009 гг. температуры воды упала на $20^{\circ} \mathrm{C}$, уменьшился рН до 6.4. На выходах подземных вод образуются травертиновые отложения, состоящие из кальцита и арагонита.

\section{ХИМИЧЕСКИЙ СОСТАВ ТЕРМАЛЬНЫХ ВОД}

Химический состав термальных и сопутствующих вод исследуемого района показан в табл. 1, а также на диаграммах рис. 2. Характерным для 
этих вод являются широкие пределы содержаний содержания аммония и бора. Котлы Верхнекошелевского термального поля в катионной части занимают область, вытянутую вдоль оси $(\mathrm{Ca}+\mathrm{Mg})$ - $\mathrm{NH}_{4}$ (см. рис. 2a), содержание $\mathrm{NH}_{4}$ значительно преобладает над $\mathrm{Na}$ и К. Максимальное количество ионов аммония (450 мг/л) обнаружено в водногрязевом котле, с соотношением воды к глинистой фракции 3 : 1 (см. табл. 1, т. 8/09в). Часть точек расположена около границы вод смешанного $\mathrm{Ca}-\mathrm{NH}_{4}$ состава. Преобладание ионов натрия и калия наблюдается только в водах термальных источников, дающих начало руч. Халцедоновый (см. рис. 2a). В двух бессточных котлах (т. 14/09в и т. 13/09в) определены высокие концентрации (более 120 мг/л) $\mathrm{Al}^{+3}$. Для грязевых котлов характерны высокие содержания бора, максимальная концентрация 173 мг/л (табл. 1, т. 8/09в). Воды руч. Восточный имеют однообразный химический состав, как на истоке (т. 1/08в), так и ниже термального поля (т. 6/08в) и относятся к $\mathrm{Ca}-\mathrm{Mg}-\mathrm{SO}_{4}$ типу. Многочисленные парогазовые струи, выходящие на поверхность непосредственно в русле ручья заметных изменений в состав воды не привносят.

Воды холодных ручьев относятся к $\mathrm{Ca}-\mathrm{Mg}-\mathrm{SO}_{4}$ типу. Сравнение полученных данных с результатами более ранних исследований [Вакин и др, 1976] показало, что макрокомпонентный состав холодных и термальных вод Верхнекошелевского термального поля в течении последних 40 лет практически не изменился.

Концентрации и распределение микроэлементов в термальных водах (табл. 2) в первую очередь определяются $\mathrm{pH}$, минерализацией, составом вмещающей породы и иногда коррелируют с некоторыми макрокомпонентами. Концентрации редких элементов в бессточных водногрязевых котлах с наивысшей минерализацией и низкими pH (т. 13/09в и т. 14/09в) практически идентичны (рис. 3a). В этих котлах зафиксированы максимальные значения ряда микрокомпонентов (в мкг/л): Ti (13), V(412), Cr (42), Mn (1.8), Co (76), Ni (53), а также Zn (239), Li (13), Rb (32), P (1.5). Наиболее высокая концентрация As (251) наблюдается в термальном источнике (т. 16/09в, см. табл. 1), а $\mathrm{Sr}$ (488) - в одном из котлов участка Дальний (т. 18/09в).

Химический состав термальных вод Нижнекошелевского поля подобен составу вод Верхнекошелевского, но, в среднем, они имеют более низкую минерализацию и различаются отношениями макрокомпонентов (см. рис. 2б) Только воды источника у озера Банное (т. 5/07) относятся к совершенно иному $\mathrm{Na}-\mathrm{HCO}_{3}$ типу. Хлор присутствует практически во всех водах в очень небольшом количестве (1-5 мг/л). Фтор обнаружен только в двух точках на Западном участке (см. табл. 1). Максимальная минерализация Нижнекошелевских термальных вод составляет 2.2 г/л (т. 1/09). В этом вод- ногрязевом котле зафиксирована высокая концентрация бора (33 мг/л) и $\mathrm{SiO}_{2}$ (128 мг/л).

Химический состав воды руч. Гремучий по мере прохождения по термальному полю претерпевает значительное изменение. До основной разгрузки термальных вод вода ручья относятся к $\mathrm{Ca}-\mathrm{HCO}_{3}$ типу с минерализацией 0.1 г/л, близнейтральным значением $\mathrm{pH}$ и температурой $10^{\circ} \mathrm{C}$. На выходе из термального поля вода Гремучего уже похожа на термальные воды, т.е. $\mathrm{NH}_{4}-\mathrm{Ca}-$ $\mathrm{SO}_{4}$ типа, со слабокислой реакцией $\mathrm{pH}=5.2$, температурой $85^{\circ} \mathrm{C}$ и общей минерализацией 0.2 г/л.

Концентрации микроэлементов в термальных водах Нижнекошелевского термального поля, в среднем, низкие. Повышенные содержания $\mathrm{P}, \mathrm{Mn}$, Rb и Ва отмечаются в т. 1/09, a Ti, V, Zn и Sr - в т. 3/09 (см. табл. 2). Сравнение концентраций микроэлементов в термальных водах Верхне- и Нижнекошелевского термальных полей (см. рис. 3б) показывает, что в среднем, их концентрации схожи. В термальных водах Верхнекошелевского поля содержится больше $\mathrm{Cu}, \mathrm{Co}, \mathrm{Ni}$, а в Нижнекошелевских - As, V.

По сравнению с ранее полученными результатами [Вакин и др, 1976] наблюдаются существенные отличия в распределении основных катионов в термальных водах Нижнекошелевского поля. Согласно данным Е.А. Вакина с коллегами, в этих водах основную роль играет не $\mathrm{NH}_{4}^{+}$, а $\mathrm{Na}^{+}$-ион, в то же время, наши данные практически повторяют результаты, представленные в работе [Сережников, 1977] (см. рис. 2б). Причины этих расхождений, вероятно, связаны с аналитическими проблемами. Источники, расположенные за пределами Нижнекошелевского термального поля, имеют схожий химический состав (см. табл. 1). Воды источников Сказка, Промежуточный и ручья Прямой относятся к $\mathrm{Ca}-\mathrm{Na}-\mathrm{HCO}_{3}$ типу (см. рис. 2б) с минерализацией 200-300 мг/л. В анионной части также стабильно присутствуют $\mathrm{Cl}^{-}$и $\mathrm{SO}_{4}^{2-}$ в небольших концентрациях.

Редкоземельные элементы (РЗЭ). Для выяснения процессов происхождения и эволюции природных вод, в том числе и термальных, в последнее десятилетие широко используются данные по геохимии редкоземельных элементов (РЗЭ). Содержания РЗЭ в водах Кошелевского массива представлены в табл. 3. В целом, термальные воды характеризуются низкими концентрациями редких земель, за исключением вод сильно упаренных водногрязевых котлов (т. 13/09в и т. 14/09в), где и их значения на порядок превышают значения, характерные для остальных термопроявленияй. На рис. 4 приведены профили распределения концентраций Р3Э в термальных водах Кошелевского массива нормированных по северо-американскому сланцу (NASC), состав которого представляет среднюю земную кору. Наиболее высокие концентрации на графике характерны для термальных вод Верхнеко- 

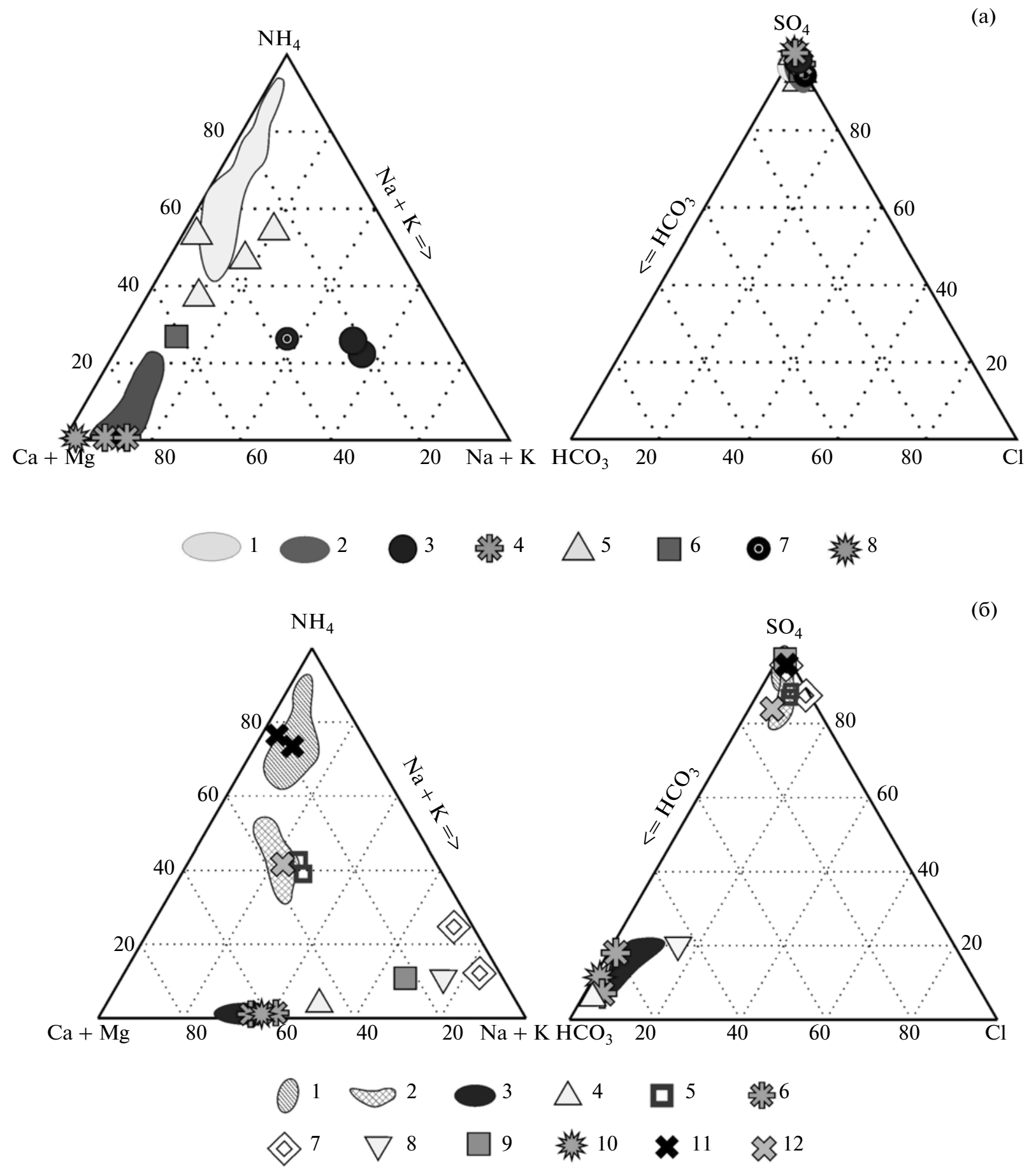

Рис. 2. Диаграммы химического состава вод.

а - Верхнекошелевское термальное поле: 1 - водногрязевые котлы; 2 - руч. Восточный; 3 - термальные источники; 4 - холодные воды; 5 - водногрязевые котлы [Вакин и др., 1976]; 6 - руч. Восточный [Вакин и др., 1976]; 7 - термальные источники [Вакин и др., 1976]; 8 - холодные воды [Вакин и др., 1976].

б - Нижнекошелевское термальное поле: 1 - водногрязевые котлы; 2 - термальные озера; 3 - термальные источники руч. Прямой; 4 - термальные источники оз. Банное; 5 - руч. Гремучий; 6 - холодные воды; 7 - водногрязевые котлы [Вакин и др., 1976]; 8 - термальные источники оз. Банное [Вакин и др., 1976]; 9 - руч. Гремучий [Вакин и др., 1976]; 10 - холодные воды [Вакин и др., 1976]; 11 - водногрязевые котлы [Сережников, 1977]; 12 - термальное озеро [Сережников, 1977]. 
(a)

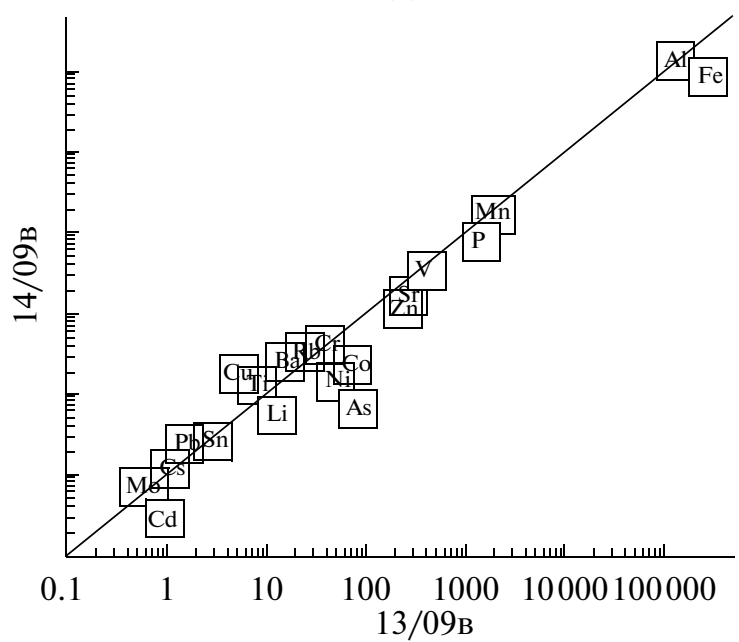

(б)

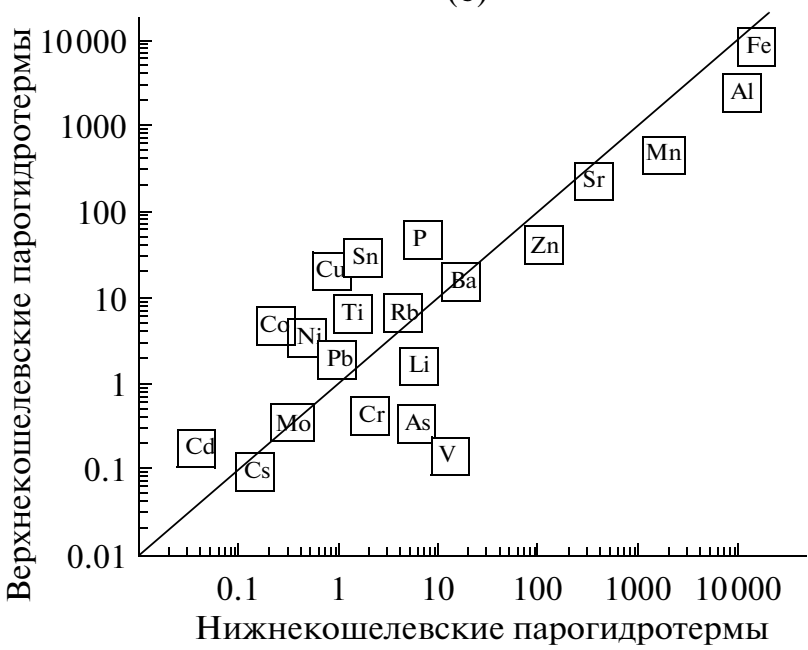

Рис. 3. Распределение соотношений концентраций микрокомпонентов.

а - в водногрязевых котлах Верхнекошелевского термального поля; б - между Верхне- и Нижнекошелевскими парогидротермами.

(a)
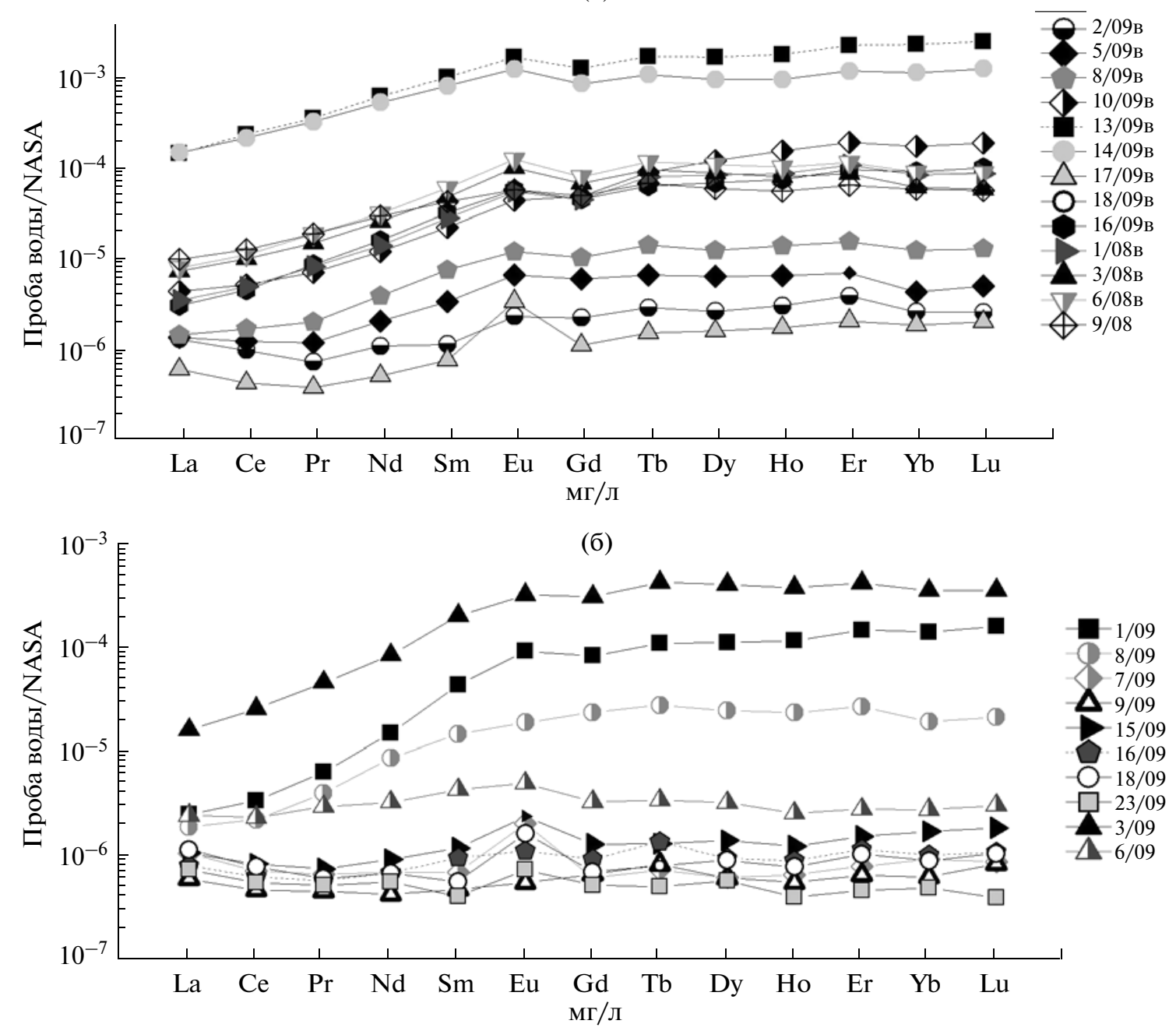

Рис. 4. Нормированные профили распределения РЗЭ.

а - Нижнекошелевские термальные воды; б - Верхнекошелевские термальные воды. 


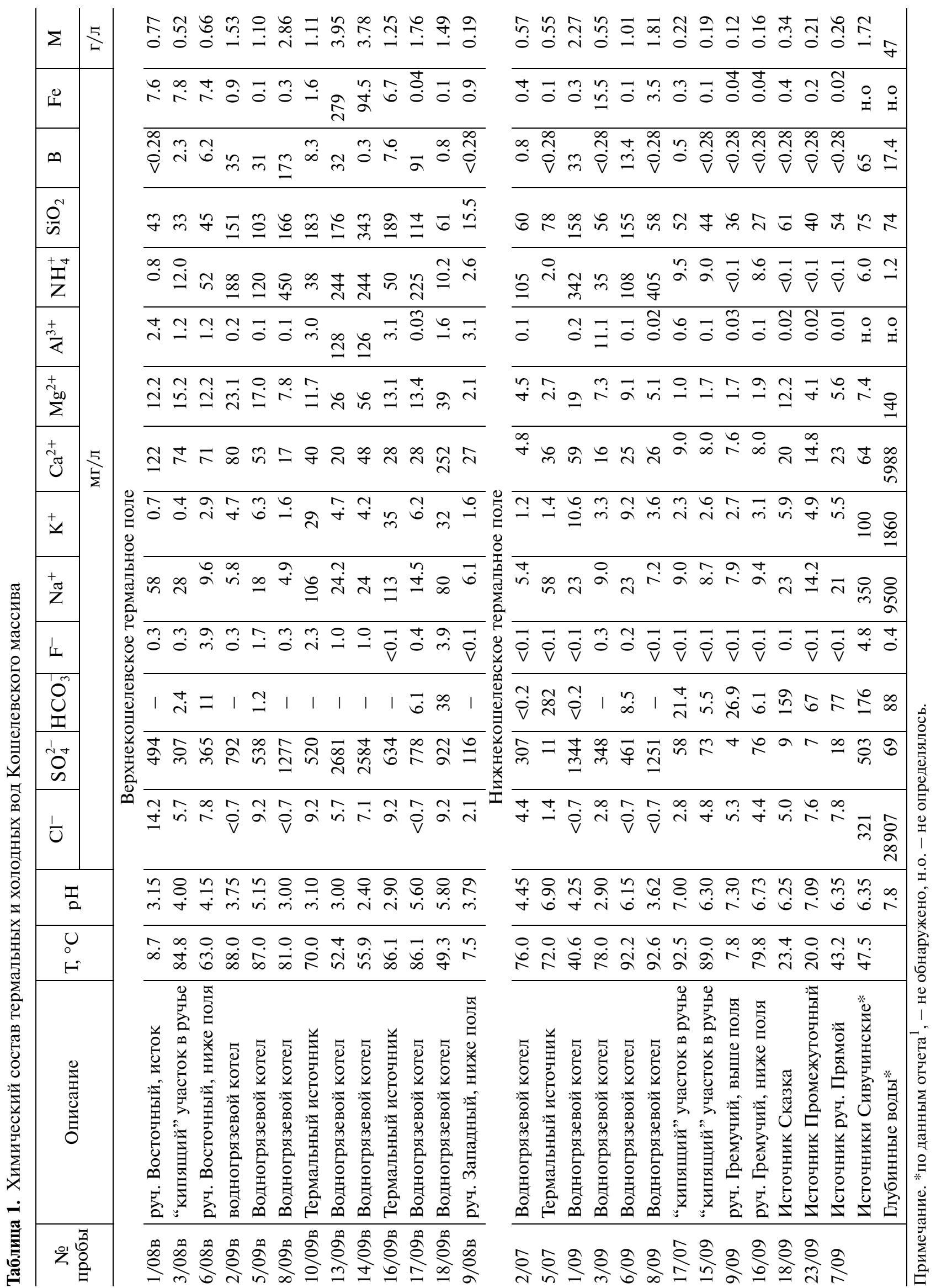




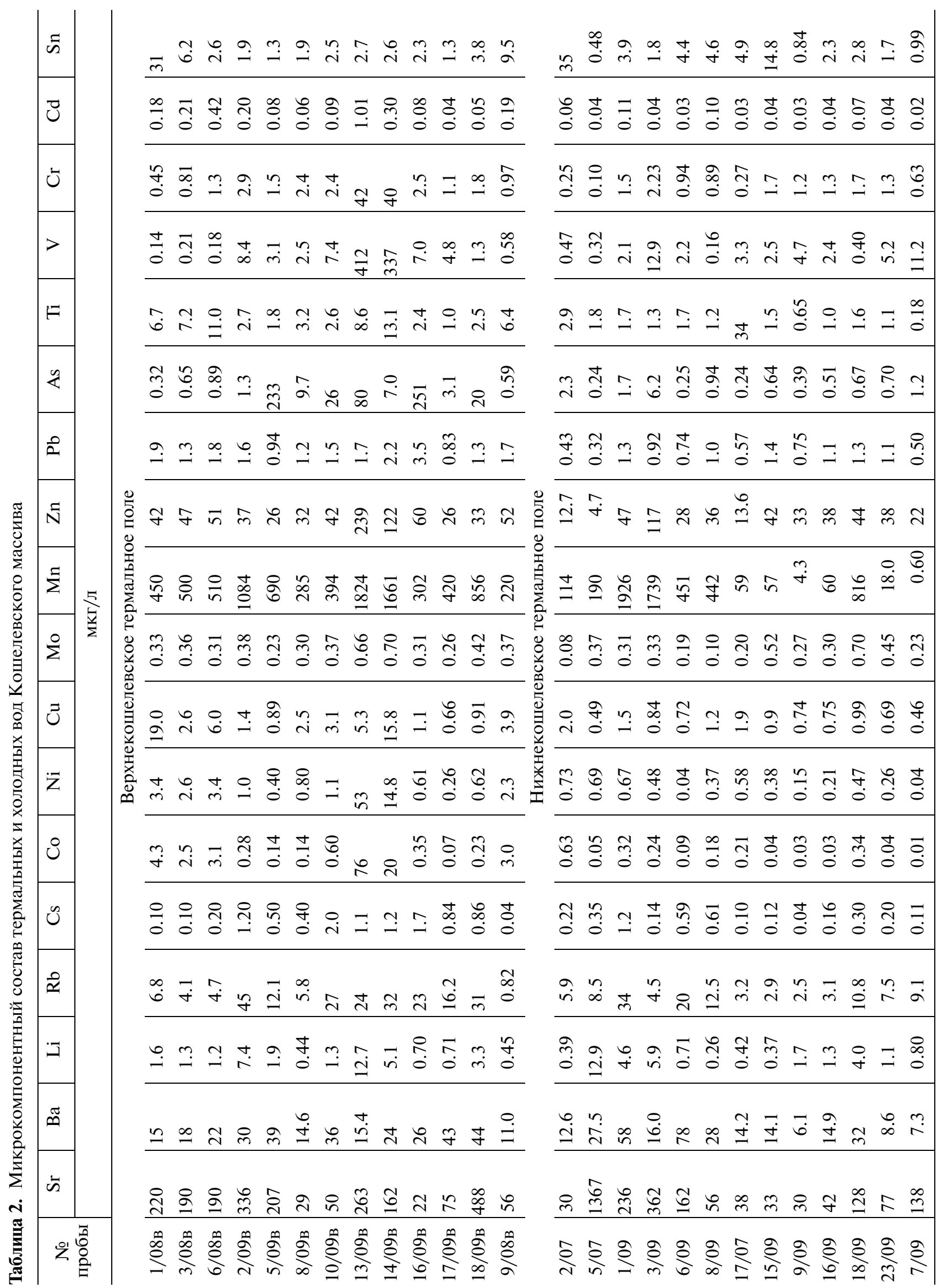


Таблица 3. Концентрации редкоземельных элементов термальных и холодных вод Кошелевского массива

\begin{tabular}{|c|c|c|c|c|c|c|c|c|c|c|c|c|c|}
\hline \multirow{2}{*}{$\begin{array}{c}\text { № } \\
\text { пробы }\end{array}$} & $\mathrm{La}$ & $\mathrm{Ce}$ & $\operatorname{Pr}$ & $\mathrm{Nd}$ & $\mathrm{Sm}$ & $\mathrm{Eu}$ & Gd & $\mathrm{Tb}$ & Dy & Ho & $\mathrm{Er}$ & $\mathrm{Yb}$ & $\mathrm{Lu}$ \\
\hline & \multicolumn{13}{|c|}{ мКг/л } \\
\hline \multicolumn{14}{|c|}{ Верхнекошелевское термальное поле } \\
\hline $1 / 08$ в & 0.110 & 0.330 & 0.066 & 0.390 & 0.160 & 0.065 & 0.290 & 0.069 & 0.510 & 0.120 & 0.350 & 0.260 & 0.040 \\
\hline 3/08в & 0.230 & 0.680 & 0.120 & 0.720 & 0.270 & 0.120 & 0.440 & 0.083 & 0.540 & 0.110 & 0.280 & 0.190 & 0.027 \\
\hline $6 / 08$ в & 0.250 & 0.750 & 0.150 & 0.870 & 0.340 & 0.150 & 0.520 & 0.100 & 0.670 & 0.140 & 0.370 & 0.280 & 0.041 \\
\hline $2 / 09 \mathrm{~B}$ & 0.041 & 0.066 & 0.006 & 0.030 & 0.006 & 0.003 & 0.014 & 0.002 & 0.016 & 0.004 & 0.013 & 0.008 & 0.001 \\
\hline $5 / 09$ в & 0.042 & 0.082 & 0.009 & 0.056 & 0.019 & 0.008 & 0.039 & 0.006 & 0.039 & 0.009 & 0.023 & 0.013 & 0.002 \\
\hline $8 / 09$ в & 0.045 & 0.114 & 0.016 & 0.108 & 0.043 & 0.014 & 0.067 & 0.012 & 0.076 & 0.019 & 0.050 & 0.039 & 0.006 \\
\hline $10 / 09 \mathrm{~B}$ & 0.139 & 0.349 & 0.057 & 0.337 & 0.126 & 0.052 & 0.314 & 0.078 & 0.729 & 0.212 & 0.624 & 0.538 & 0.088 \\
\hline $13 / 09 \mathrm{~B}$ & 4.55 & 15.86 & 2.85 & 17.29 & 5.74 & 2.01 & 8.24 & 1.48 & 10.33 & 2.49 & 7.38 & 7.27 & 1.16 \\
\hline $14 / 09 \mathrm{~B}$ & 4.66 & 14.49 & 2.61 & 14.71 & 4.58 & 1.50 & 5.58 & 0.936 & 5.82 & 1.31 & 3.85 & 3.53 & 0.580 \\
\hline $16 / 09 \mathrm{~B}$ & 0.097 & 0.304 & 0.070 & 0.446 & 0.183 & 0.069 & 0.293 & 0.055 & 0.416 & 0.103 & 0.310 & 0.283 & 0.047 \\
\hline $17 / 09 \mathrm{~B}$ & 0.019 & 0.028 & 0.003 & 0.014 & 0.004 & 0.004 & 0.007 & 0.001 & 0.010 & 0.002 & 0.007 & 0.006 & 0.001 \\
\hline $18 / 09 \mathrm{~B}$ & 0.046 & 0.100 & 0.013 & 0.078 & 0.039 & 0.023 & 0.149 & 0.040 & 0.326 & 0.078 & 0.213 & 0.135 & 0.020 \\
\hline $9 / 08 \mathrm{~B}$ & 0.310 & & & 0.820 & 0.240 & 0.069 & 0.320 & 0.058 & 0.360 & 0.077 & 0.210 & 0.180 & 0.026 \\
\hline \multicolumn{14}{|c|}{ Нижнекошелевское термальное поле } \\
\hline $1 / 09$ & 0.073 & 0.214 & 0.048 & 0.384 & 0.228 & 0.102 & 0.498 & 0.087 & 0.629 & 0.148 & 0.443 & 0.404 & 0.068 \\
\hline $3 / 09$ & 0.470 & 1.61 & 0.343 & 2.17 & 1.06 & 0.354 & 1.84 & 0.335 & 2.27 & 0.479 & 1.25 & 1.01 & 0.151 \\
\hline $6 / 09$ & 0.072 & 0.148 & 0.022 & 0.085 & 0.023 & 0.006 & 0.020 & 0.003 & 0.018 & 0.003 & 0.009 & 0.008 & 0.001 \\
\hline $8 / 09$ & 0.056 & 0.140 & 0.030 & 0.227 & 0.077 & 0.021 & & 0.022 & 0.140 & 0.030 & & 0.055 & 0.009 \\
\hline $15 / 09$ & 0.031 & 0.053 & 0.006 & 0.024 & 0.006 & 0.003 & 0.008 & 0.001 & 0.008 & 0.002 & 0.005 & 0.005 & 0.001 \\
\hline $9 / 09$ & 0.018 & 0.030 & 0.003 & 0.011 & 0.003 & 0.001 & 0.004 & 0.001 & 0.003 & 0.001 & 0.002 & 0.002 & 0.0004 \\
\hline $16 / 09$ & 0.024 & 0.040 & 0.004 & 0.018 & 0.005 & 0.001 & 0.006 & 0.001 & 0.005 & 0.001 & 0.003 & 0.003 & 0.0005 \\
\hline $18 / 09$ & 0.034 & 0.049 & 0.005 & 0.018 & 0.003 & 0.002 & 0.004 & 0.001 & 0.005 & 0.001 & 0.003 & 0.003 & 0.0005 \\
\hline $23 / 09$ & 0.022 & 0.035 & 0.004 & 0.014 & 0.002 & 0.001 & 0.003 & 0.0004 & 0.003 & 0.001 & 0.001 & 0.001 & 0.0002 \\
\hline 7/09 & 0.031 & 0.045 & 0.005 & 0.018 & 0.004 & 0.002 & 0.004 & 0.001 & 0.004 & 0.001 & 0.002 & 0.003 & 0.0004 \\
\hline
\end{tabular}

шелевского поля (см. рис. 4a), а самые низкие - для нейтральных, низко-минерализованных термальных вод, разгружающихся ниже Нижнекошелевского термального поля (см. рис. 4б). Верхнекошелевские воды обогащены тяжелыми РЗЭ. Профили распределения РЗЭ для различных типов вод Нижнекошелевского поля отличаются друг от друга. Для вод бессточных водногрязевых котлов с низкими значениями $\mathrm{pH}$ характерно обогащение тяжелыми РЗЭ. Для вод руч. Гремучий и “кипящих” участков в его русле характерно практически равномерное распределение значений с небольшой положительной Eu-аномалией. Схожее распределение характерно и для термальных вод, разгружающихся за пределами Нижнекошелевского поля. Положительная Eu-аномалия в воде является, возможно, следствием присутствия в водовмещающих породах минеральных фаз, обогащенных данным элементом, а также может свидетельствовать, о более восстановительной обстановке формирования этих вод [Wood, 2003; Peiffer et al., 2011].
Изотопный состав стронция ( $\underline{87} \underline{\mathrm{Sr}} / \underline{86} \underline{\mathrm{Sr}})$. Разброс значений отношений ${ }^{87} \mathrm{Sr} /{ }^{86} \mathrm{Sr}$ в термальных водах как Верхне-, так и Нижнекошелевского термальных полей очень небольшой и составляет в среднем 0.7032-0.7034. Более высокие значения отмечены в одном из кипящих котлов озера Термальное и в источниках, дающих начало ручью Халцедоновый (рис 5). Значения ${ }^{87} \mathrm{Sr} /{ }^{86} \mathrm{Sr}$ для неизмененных андезито-базальтов Кошелевского вулкана [Структура ..., 1993] составляет 0.7030, для дацитов - 0.7032. Таким образом, Sr в термальных водах Кошелевского массива имеет изотопный состав практически не отличающийся от изотопного состава Sr породы. Воды руч. Гремучий выше термального поля и питающие его снеговые воды характеризуются более высокими изотопными отношениями стронция, близкими к морским. Ранее показано [Пампура, 1985], что снеговые и талые воды Паужетской вулкано-тектонической депрессии, в целом, заражены растворенным Sr c "морским" изотопным соотноше- 


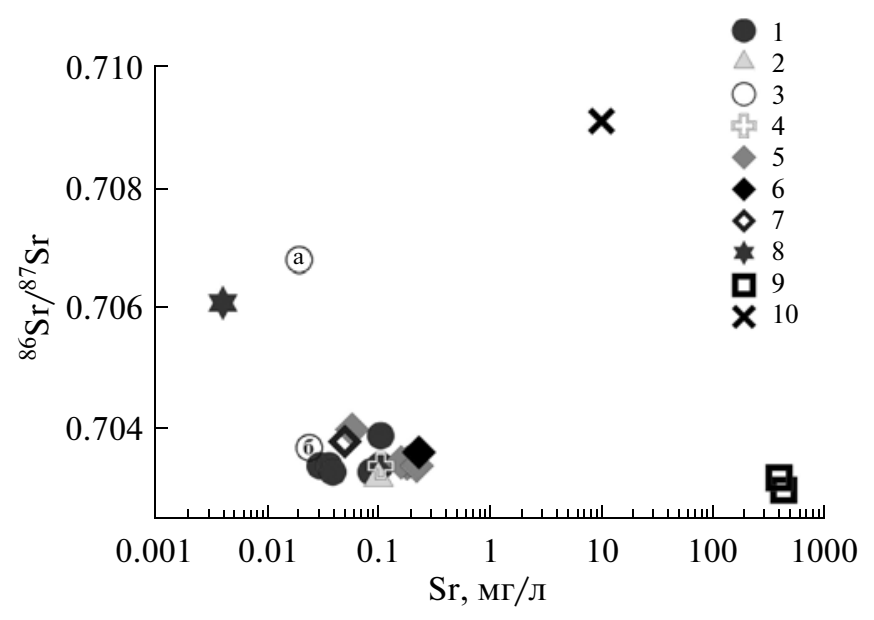

Рис. 5. Распределение изотопов стронция в водах Кошелевского массива.

Нижнекошелевское термальное поле: 1 - водногрязевые котлы; 2 - конденсат из скважины [Структура ..., 1993]; 3 - руч. Гремучий: а - выше термального поля, б - ниже термального поля; 4 - источники руч. Прямого; Верхнекошелевское термальное поле: 5 - водногрязевые котлы; 6 - руч. Восточный, ниже термального участка Тартарары; 7 - р. Шумная, ниже термального поля; 8 - снег; 9 - вмещающие породы; 10 - Охотское море.

нием (0.7090) за счет воздействия близлежащей морской акватории.

\section{УСЛОВИЯ ФОРМИРОВАНИЕ ТЕРМАЛЬНЫХ ВОД КОШЕЛЕВСКОГО МАССИВА}

Оба термальных поля - Верхнекошелевское и Нижнекошелевское представляют собой разгрузку подземного пара, который, судя по данным бурения [Писарева, 1987] образует устойчивую паро-доминирующую зону в постройке вулканического массива. Пар в наиболее проницаемых зонах разгружается в виде парогазовых струй с температурами близкими или к температуре кипения на данной высоте, или "перегретыми" до $150^{\circ} \mathrm{C}$ в пределах Верхнекошелевского поля. Температуры гидротермальных фумарол выше $100^{\circ} \mathrm{C}$ известны и на других термальных полях. Самые известные - фумаролы Бокка Нуова и Бокка Гранде в кратере Сольфатара Флегрейских полей [Caliro et al., 2007]. В менее проницаемых, и более обводненных зонах пар смешивается с грунтовыми водами, конденсируется, и образуются термальные источники или малосточные и бессточные водногрязевые котлы. Согласно Вакину и др. (1976), состав газа Верхне- и Нижнекошелевских парогазовых струй является типичным для высокотемпературных гидротермальных систем с паро-доминирующей зоной [Таран, 1988; Chiodini and Marini, 1998] т.е. содержит высокие концентрации $\mathrm{CO}_{2}$ и $\mathrm{H}_{2} \mathrm{~S}$. При смешении с грунтовыми водами сероводород окисляется кислородом воздуха до сульфата, и образующиеся, так называемые, нагретые паром воды (steam-heated waters), [Giggenbach and Stewart, 1982] становятся кислыми и активно реагируют с вмещающей породой. Поэтому можно полагать, что вся катионная нагрузка, а также основной набор микроэлементов в Кошелевских термальных водах, обусловлены приповерхностным взаимодействием вода-порода. Это же относится к распределению РЗЭ и к изотопному составу стронция. Они отражают состав измененных пород термальных полей.

Согласно Рожкову и Верховскому (1990), концентрация Не в газах Нижне-Кошелевского термального поля составляет 20-30 ppm (в сухом газе), а отношение ${ }^{3} \mathrm{He} /{ }^{4}$ Не около $1.1 \times 10^{-5}$, т.е. индикаторное отношение $\mathrm{C} /{ }^{3} \mathrm{He} \approx 3 \times 10^{9}$, означающее, что $\mathrm{CO}_{2}$ в Кошелевских газах имеет магматическое происхождение. К особенностям Кошелевского газа нужно отнести высокие концентрации метана и углеводородов [Бескровный и Лобков, 1977; Вакин и др. 1976]. По данным отчета ${ }^{1}$ конденсаты пара из паровых скважин характеризовались большими вариациями концентраций аммония (от 5 до 130 мг/л) и низкими концентрациями борной кислоты, как правило, ниже 10 мг/л. Высокоминерализованная вода, вскрытая некоторыми скважинами на глубинах более 1000 м с концентрациями хлор-иона до 30 г/л, содержала менее 10 мг/л аммония и до 20-50 мг/л бора. Высокие концентрации бора (35 мг/л) при содержании $\mathrm{Cl}^{-} 321$ мг/л характерны и для вод Сивучинских термальных источников (см. табл. 1), расположенные у подножия Кошелевского массива. Представляется, что аммоний и бор в конденсатных водах обоих Кошелевских термальных полей привносятся с паром, который отделился от водного высокоминерализованного раствора, циркулирующего в глубинах гидротермальной системы. Непостоянство концентраций бора (борной кислоты) в гидротермальном паре может быть связано, как показано в работе [Bernard et al., 2012], с температурой начала кипения водного раствора, с вариациями отношения пар/вода в двухфазной зоне и с начальной концентрацией бора в материнском растворе. Похожее поведение и у пары аммоний-аммиак. Высокие концентрации бора и аммония, вероятнее всего, связаны с упариванием термальных вод, что хорошо видно на рис. 6 , где показана достаточно высокая корреляция между бором, аммонием и сульфат-ионом. Наибольшие концентрации этих компонентов оказываются в бессточных котлах.

\footnotetext{
${ }^{1}$ Писарева М.В., Судакова И.А., Нажалова И.Н. и др. Отчет о поисковых работах, проведенных на Нижне-Кошелевском месторождении парогидротерм в 1975-1984 гг.(в 3-х томах). Том I. Термальный. 1984.
} 

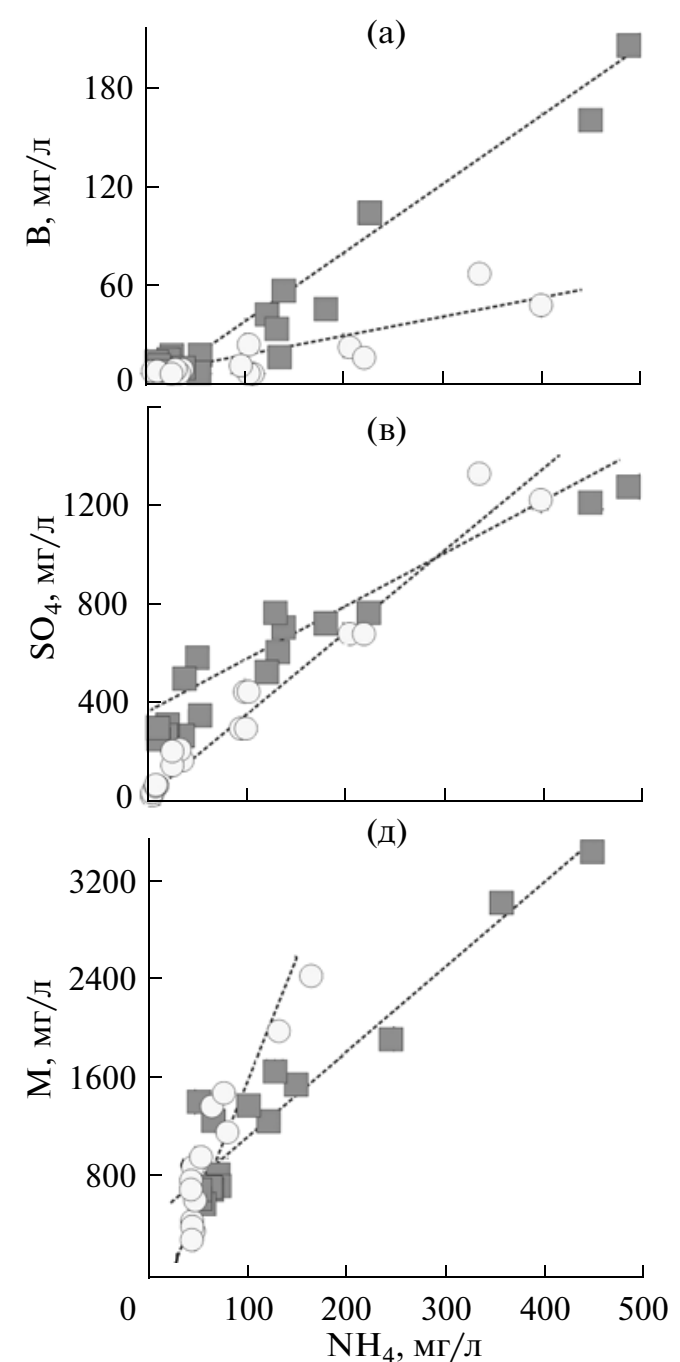
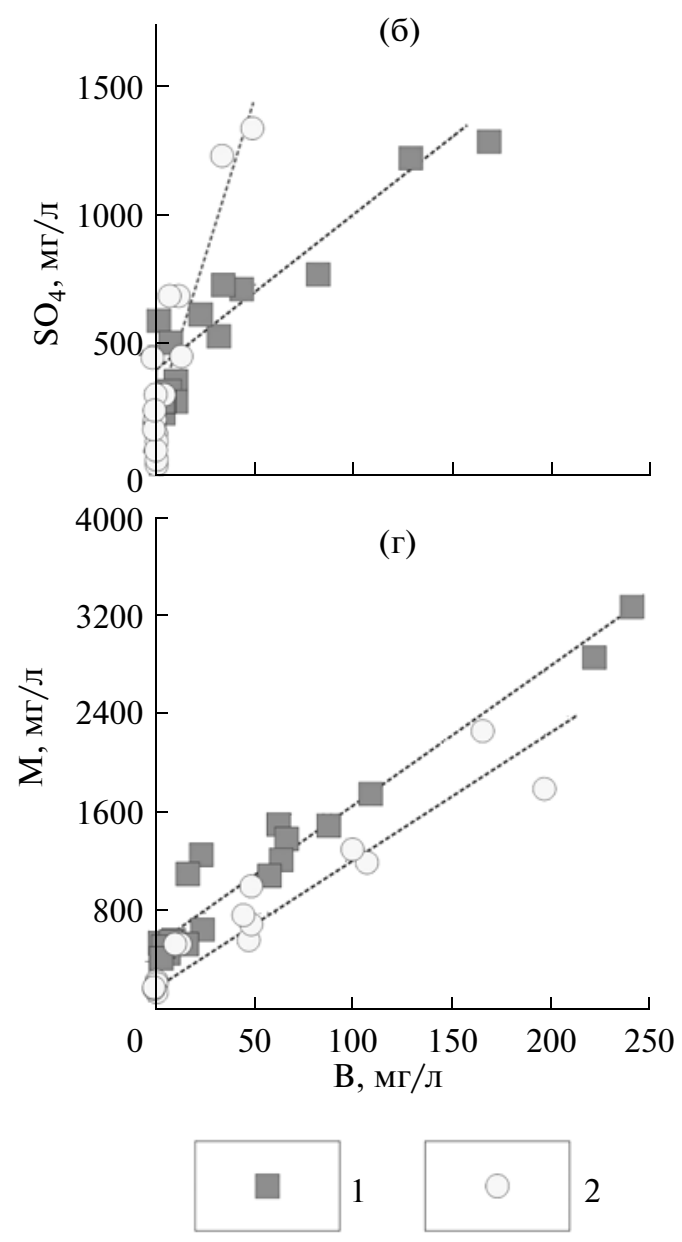

Рис. 6. Распределения соотношений концентраций отдельных компонентов в термальных водах.

1 - Верхнекошелевское термальное поле; 2 - Нижнекошелевское термальное поле.

В районе Нижнекошелевского термального поля в ходе геологоразведочных работ, проводимых в 70-ые годы XX века осадочные породы не были вскрыты, вероятно, вследствие недостаточной глубины скважин. Но на побережье Охотского моря на глубине более 1 км по данным ${ }^{1}$ вскрыт фундамент Кошелевского вулканического массива, представленный интенсивно измененными вулкано- терригенными песчаниками Березовской свиты среднемиоценового возраста, содержащими органические остатки и битум. Подземные воды, циркулирующие в неогеновых отложениях относятся к перегретым $\mathrm{Na}-\mathrm{Cl}$ рассолам. Химический состав их представлен в таблице 1. На наличие нефтепродуктов на глубине указывает также и значительные содержания в Нижнекошелевских термальных водах (до 0.4 мг/л) и в конденсате из скважин (до 1.12 мг/л) нафтеновых кислот (по данным ${ }^{1}$ ). Экспериментальные иссле- дования [Швец, 1973] показали, что при температуре выше $200^{\circ} \mathrm{C}$ воды хлоридно-натриевого состава активно экстрагируют из осадочных пород органические соединения, в первую очередь азотсодержащие вещества, нейтральные смолы и нафтеновые кислоты. Возможно, за счет термического разложения органических остатков происходит высвобождение аммиака из пород и переход его в жидкую фазу в виде ионов аммония. С наличием нефтепродуктов в этих породах может быть связано и появление в термах борной кислоты. Дополнительным источником бора может служить ангидрит, широко распространенный в отложениях Березовской свиты. Известно, что ангидрит осадочных пород обычно характеризуется высоким содержанием водорастворимого бора [Озол, 1983] и при взаимодействии с гидротермальными растворами может выноситься до $80 \%$ рассеянного в породе бора. 


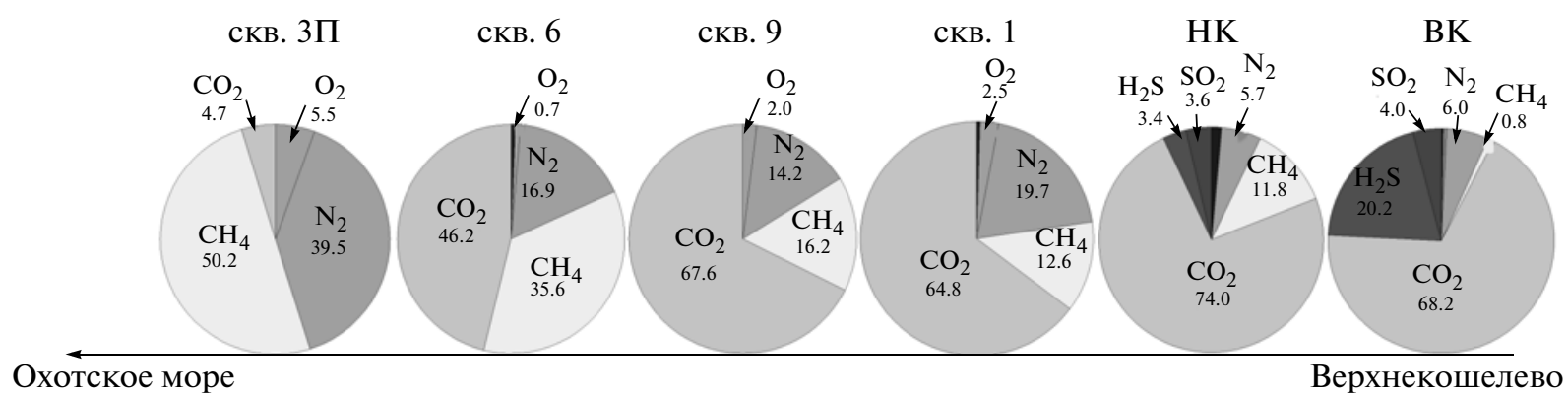

Рис. 7. Распределение газа (в об. \%) в естественных выходах гидротерм и в конденсатах из скважин Кошелевского вулканического массива.

\section{ПРЕДВАРИТЕЛЬНАЯ КОНЦЕПТУАЛЬНАЯ МОДЕЛЬ КОШЕЛЕВСКОЙ ГИДРОТЕРМАЛЬНОЙ СИСТЕМЫ}

На основании вышесказанного, с учетом анализа опубликованных данных по исследуемому району и существующих представлений о пародоминирующих гидротермальных системах [Ellis and Mahon, 1977; Truesdell and White, 1983; Таран, 1988; Писарева, 1987; и др.] можно предложить предварительную концептуальную модель Кошелевской гидротермальной системы.

Источником тепла для системы служит внутрикоровый магматический очаг, определенный геофизическими исследованиями с центром на глубине 10 км [Вакин и др, 1976]. Высокие отношения ${ }^{3} \mathrm{He} /{ }^{4} \mathrm{He}$ до $7 \mathrm{Ra}$, где $\mathrm{Ra}$ атмосферное отношение $1.4 \times 10^{-6}$, [Рожков, Верховский, 1990] указывают на то, что гидротермы района формируются за счет тепловой энергии внедренной в кору магмы. Однако существенным источником поступления вещества в гидротермальную систему являются также вмещающие вулканогенно-осадочные отложения неогенового возраста. За счет взаимодействия гидротермальных растворов с богатыми органикой вмещающими породами в условиях высоких температур, происходит переход в водную фазу аммиака, бора, метана. В зоне кипения в пар переходят практически целиком все растворенные газы и частично борная кислота и аммиак [Таран, 1988; Bernard et al., 2011]. В низко проницаемой зоне над зоной кипения образуется устойчивая паровая шапка с температурой около $240^{\circ} \mathrm{C}$, источник паровых струй и их дериватов на поверхности Нижне- и Верхнекошелевских термальных полей. Температуры паровых струй до $160^{\circ} \mathrm{C}$ (перегретый пар) - характерный признак наличия парового резервуара. В приповерхностных условиях часть парогазовой смеси адсорбируются грунтовыми водами, насыщенными кислородом. Окисление $\mathrm{H}_{2} \mathrm{~S}$ до $\mathrm{H}_{2} \mathrm{SO}_{4}$ приводит к образованию кислых сульфатных вод. С паром также переносятся борная и нафтеновые кислоты и аммиак. В зависимости от физико-химических усло- вий выхода парогидротерм на поверхности формируются основные формы термопроявлений на участках, представленные парогазовыми струями, кипящими водногрязевыми котлами, термальными источниками и бессточными водоемами. Центральная часть системы находится ближе к Верхнекошелевскому термальному полю. Несмотря на то, что термальные воды это термального поля расположены выше на 500 м, по выносу тепла они практически вдвое превосходят Нижнекошелевские. Кроме того, на это указывает и распределение газа в естественных выходах и скважинах, пробуренных на западном склоне массива. В центральных частях гидротермальных систем подавляющее значение имеет углекислый газ, тогда как количество метана в центре минимально, а на окраине он практически заменяет углекислый газ [Поздеев, Нажалова, 2008]. Подобное распределение газов наблюдается в естественных выходах и в скважинах, пробуренных на западном склоне Кошелевского массива от Верхнекошелевского термального поля до Охотского побережья (рис. 7). Уровень подземных вод на начальных стадиях формирования термоаномалий был близок к поверхности, в настоящей время жидкая фаза находится на глубине не менее двух км под уровнем моря [Писарева, 1987]. Столь сильное понижение положения водного зеркала отчасти может быть связано с тем, что за время деятельности гидротермальной системы, сформировались значительные депрессионные воронки вокруг выходов геотермального пара. Подземные воды верхнего горизонта движутся по уклону к местному базису дренирования, практически не попадая в область влияния депрессионных воронок за счет низких фильтрационных свойств четвертичных отложений, а пополнение системы происходит за счет стягивания в центральную зону подземных вод, область питания которых находится за пределами массива, что подтверждается данными бурения. Пробуренными скважинами ${ }^{1}$ по линии до Охотского моря зафиксировано движение подземных вод к центру системы. 


\section{ЗАКЛЮЧЕНИЕ}

Термальные воды, разгружающиеся в пределах Кошелевского вулканического массива, имеют температуру до $98^{\circ} \mathrm{C}$ и, в основном, относятся к кислым или слабокислым ( $\mathrm{pH}=3-5.8)$ сульфатным, аммониевым или $\mathrm{Ca}(\mathrm{Na})$-аммониевым с повышенным содержанием кремнекислоты (95-175 мг/л). Общая минерализация составляет, в среднем, $0.6-0.8$ г/л и может достигать 2.5 г/л (в водногрязевых котлах), а рН меняется в широких пределах от 2.4 до 7.0. Высоких концентрации аммония и бора в термальных водах Кошелевского массива, и возможно других компонентов обязано взаимодействием глубинного гидротермального раствора с неогеновыми вулканогенно-осадочными породами, лежащими в основании массива. За счет термического разложения органического вещества при высоких Р-Т (давление + температура) параметрах среды происходит высвобождение из пород метана, аммиака и борной кислоты и переход этих компонентов в раствор и в паровую фазу. Значительные вариации концентраций аммония и бора, а также сульфат-иона связаны с поверхностными процессами разбавления и упаривания. Предложенная концептуальная модель объединяет Верхнекошелевские и Нижнекошелевские термальные поля, как поверхностные проявления единой системы, центральная часть которой непосредственно связана с Верхнекошелевскими парогазовыми выходами.

Авторы признательны всем коллегам по экспедиционным работам за практическую помощь в получении фактического материала и сотрудникам аналитических служб Института геохимии СО РАН и Института вулканологии и сейсмологии ДВО РАН за большой объем лабораторных исследований. Авторы благодарны В.М. Сугробову и А.В. Кирюхину за ценные замечания. Работа выполнена при финансовой подлержке Российского фонда фундаментальных исследований (проект 1305-00262а) и Дальневосточного отделения РАН.

\section{СПИСОК ЛИТЕРАТУРЫ}

Бескровный Н.С., Лобков В.А. Закономерности распротранения углеводородных газов в современных гидротермальных системах Камчатки // Гидротремальный процесс в областях тектоно-магматической активности. М.: Наука, 1977. С 110-119.

Вакин Е.А., Декусар З.Б., Сережников А.И., Спиченкова М.В. Гидротермы Кошелевского вулканического массива // Гидротермальные системы и термальные поля Камчатки. Владивосток: ДВНЦ АН СССР, 1976. С. $58-84$.

Геолого-геофизический атлас Курило-Камчатской островной системы / Под ред. Сергеева К.Ф., Красного М.Л. Л.: ВСЕГЕИ, 1987. 36 л.

Долгоживущий центр эндогенной активности Южной Камчатки. М.: Наука, 1980. 172 с.
Лебедев М.М., Декусар 3.Б. Проявление углеводородов в термальных водах Южной Камчатки // Вулканология и сейсмология. 1980. № 5. С. 93-97.

Манухин Ю.Ф., Павлова Л.Е. Типизация гидрогеологических структур вулканических районов Камчатки и характеристика вулканогенных бассейнов // Вулканология и сейсмология. 2011. № 3. С. 13-33.

Нуждаев И.А., Феофилактов С.О. Современное состояние изученности строения центральной части Нижне-Кошелевского геотермального месторождения (Южная Камчатка) и результаты магнитной съемки // Вестник КРАУНЦ. Науки о Земле. 2013. № 2 (22). C. 231-241.

Озол А.A. Осадочный и вулканогенно-осадочный рудогенез бора. М.: Наука, 1983. 208 с.

Писарева М.В. Зона природного пара Нижнекошелевского геотермального месторождения // Вулканология и сейсмология. 1987. № 2. С. 52-63.

Поздеев А.И., Нажалова И.Н. Геология, гидродинамика и нефтегазоносность Кошелевского месторождения парогидротерм // Вулканология и сейсмология. 2008. № 3. C. 32-45.

Рожсков А.М. Верховский А.Б. Геохимия благородных газов высокотемпературных гидротерм. М.: Наука, $1990.133 \mathrm{c}$.

Рычагов С.Н. Гигантские газо-гидротермальные системы и их роль в формировании пародоминирующих геотермальных месторождений и рудной минерализации // Вулканология и сейсмология. 2014. № 2. С. 3-28.

Рычагов С.Н., Давлетбаев Р.Г., Ковина О.В. Гидротермальные глины и пирит геотермальных полей: значение в геохимии современных эндогенных процессов (Южная Камчатка) // Вулканология и сейсмология. 2009. № 2. C. 39-56.

Рычагов С.Н., Давлетбаев Р.Г., Ковина О.В. и др. Миграция катионов в гидротермальных глинах: к вопросу о критериях металлоносности газо-гидротермальных флюидов геотермальных месторождений Южной Камчатки // Вулканология и сейсмология. 2012. № 4. C. 23-36.

Сережников А.И. Современные сульфатные гидротермы в районе Кошелевского вулкана (Южная Камчатка), их соотношения с вулканизмом и низкотемпературным выщелачиванием // Гидротермальный процесс в областях тектоно-магматической активности. М: Наука, 1977. С. 184-193.

Сережников А.И., Литасов Н.Е., Огородов Н.В., Спиченкова М.В. Кошелевский вулканический массив // Бюлл. вулканол. станций. 1973. № 49. С. 54-59.

Сережников А.И., Спиченкова М.В. Геология и подземные воды Кошелевского вулканического массива (Камчатка) // ДАН. 1978. Т. 240. № 3. С. 681-684.

Структура гидротермальной системы. М.: Наука, 1993. $298 \mathrm{c}$.

Таран Ю.А. Геохимия геотермальных газов. М.: Наука. 1988. $168 \mathrm{c}$.

Швец В.М. Органические вешества подземных вод. М.: Недра, 1973. 192 с.

AquaChem v.5.1. User's manual. Water Quality Data Analysis, Plotting, and Modeling. Waterloo Hydrogeologic, Inc. 2006. 366 p. 
Bernard R., Taran Y., Pennisi M. et al. Chloride and Boron behavior in fluids of Los Humeros geothermal field (Mexico). A model based on the existence of deep acid brine // Applied Geochemistry. 2011. V. 26. P. 2064-2073.

Caliro S., Chiodini G., Moretti R. et al. The origin of the fumaroles of La Solfatara (Campi Flegrei, South Italy) // Geochim. Cosmochim. Acta. 2007. V. 71. P. 3040-3055.

Chiodini G., Marini L. Hydrothermal gas equilibrium, the $\mathrm{H}_{2} \mathrm{O}-\mathrm{H}_{2}-\mathrm{CO}_{2}-\mathrm{CO}-\mathrm{CH}_{4}$ system // Geochim. Cosmochim. Acta. 1998. V. 62. P. 2673-2687.

Ellis A.J., Mahon W.A.J. Chemistry and geothermal systems. N.Y. Acad. 1977. 392 p.

Giggenbach W.F., Stewart M.R. Processes controlling the isotopic composition of steam and water discharges from steam vents and steam-heated pools in geotermal areas // Geothermics. 1982. V. 11. P. 71-80.
Peiffer L., Taran Y., Lounejeva E. et al. Tracing thermal aquifers of $\mathrm{El}$ Chichon volcano-hydrothermal system (Mexico) with ${ }^{87} \mathrm{Sr} /{ }^{86} \mathrm{Sr}, \mathrm{Ca} / \mathrm{Sr}$ and REE // Volcanol. Geotherm. Res. 2011. V. 205. P. 55-66.

Sano $Y$. and Marty B. Origin of carbon in fumarolic gases from island arcs // Chem. Geology. 1995. V. 119. P. 265-274.

Truesdell A.H., White D.E. Production of super-heated steam from vapor-dominated reservoirs // Geothermics, 1983. V. 2. P. $154-173$.

Wood S.A. The geochemistry of rare earth elements and yttrium in geothermal waters // Volcanic, geothermal and ore-forming fluids: rules and witnesses of processes within the Earth. Society of Econom. Geologists. 2003. V. 10. P. $133-158$. 